\title{
The Analysis of the Concept of Empathy Skill in Postgraduate Social Studies Theses
}

\author{
Selma Güleç ${ }^{1}$ \\ ${ }^{1}$ Faculty of Education, Bursa Uludag University, Bursa, Turkey \\ Correspondence: Selma Güleç, Faculty of Education, Bursa Uludag University, Bursa, Turkey.
}

Received: December 15, 2019

Accepted: February 12, $2020 \quad$ Online Published: March 21, 2020

doi:10.5539/ies.v13n5p24

URL: https://doi.org/10.5539/ies.v13n5p24

\begin{abstract}
The skill of empathy is mentioned among the basic skills included in the Social Studies Course Teaching Program of the Ministry of National Education. The social studies course is one of the most important courses in which students are made to acquire the information, skills and values which are required to become an effective citizen. Communication has an important place in the achievement of these goals. Empathy is very important in the establishment of effective communication. For this reason, the study aimed to examine the concept of empathy, one of the basic skills included in the Social Studies Course Teaching Program. Afterwards, in the study, it was also aimed to reveal if the students taking postgraduate education in universities in Turkey investigated into the skill of empathy included in the social studies course teaching program in terms of carious variables. For this purpose, the master's and doctoral theses written under the heading of empathy in the field of Social Studies Education at universities in Turkey between the years of 2000 and 2019 and recorded at the official website of the Higher Education Council National Thesis Center were examined. A total of 17 theses were reached. The data of the study was evaluated in tems of the publication year of the thesis, the gender of the researcher, the university where it was published, the sample groups, the methods of investigation and the subjects of investigation. In the study, the document analysis technique, one of the qualitative research methods, was used.
\end{abstract}

Keywords: social studies, social studies teaching, empathy skill, postgraduate thesis

\section{Introduction}

Social Studies is an area where all Social Sciences, philosophy and other activities intersect one another. There are many definitions about Social Studies dealing with human being and life. Social Studies is a process of establishing a connection based on proving social realities and life information obtained as a result of this (Sönmez, 1999). Social Studies is an area of study taking in hand the interaction of human with his physical and social environment with an interdisciplinary approach within time dimension by benefiting from the contents and methods of social and other sciences related to human being and aiming to raise thinking and skillful democratic citizens equipped with basic democratic values related to life in a globalizing world (Doğanay, 2004). According to Öztürk (2006), social studies is a teaching program using by integrating the information which it takes from social sciences and humanities with the aim of raising effective individuals being able to solve problems under country and world conditions changing in all aspects. With the course of Social Studies, it is aimed to have individuals acquire the awareness of fulfilling their responsibilities in the development and popularization of citizenship, human rights and democracy (Tezgel, 2006).

Social studies teaching has an important role in equipping individuals with knowledge and skills to help them adapt to social life. Having students acquire knowledge, skills and values required to become a good citizen by means of education is achieved especially thanks to the Social Studies course. Thanks to education, particularly the Social Studies course, students are provided with necessary knowledge, skills and values so that they can become a good citizen. The Social Studies course is important in terms of having students acquire the personal characteristics and democratic attitudes required to participate in a democratic society effectively (Ersoy \& Kaya, 2008). The social studies teaching program aims to develop positive behaviors in individuals in political, cultural, social and economic areas (Öztürk et al., 2002).

It is stated that the social studies course addresses children aged 9-13 years and knowledge, skills and values which children will acquire in this period will be difficult to change in the advancing ages. For this reason, for a child in this age group, the social studies course is of separate importance (Akdağ, 2009). Thanks to this course, students 
are raised as individuals who can think critically in every area by using upper level thinking skills, know how to obey rules, can act in harmony with individuals around them and have democratic citizenship skills. The social studies course aims to raise individuals who are able to think critically in every field by using high level thinking skills, know how to follow the rules, act in harmony with the people around them and have democratic citizenship skills. The social studies course takes the lead in having students acquire knowledge, skills and attitudes to help their individual and social lives (Yiğit, 2007). With the use of empathy in the social studies, it might be possible to raise individuals being in harmony with the society, arranging their lives in accordance with democratic rules, having social sensitivity, being open to novelties and being able to keep up with changes.

\subsection{The Concept of Empathy}

Today, when empathy is mentioned, Carl Rogers' way of taking in hand empathy comes to mind. According to Rogers, empathy is the process of a person's understanding the emotions and thoughts of another person correctly in relation to a certain situation, feeling what that person feels and delivering this situation to him/her. According to Dökmen (2013), empathy is defined as one's understanding another's emotions and thoughts correctly by putting $\mathrm{him} /$ herself in his/her place. According to Dökmen, the factors required for an individual to establish empathy with another are these:

a. A person establishing empathy is required to put him/herself into another's place and look at events through his/her eyes. And in order to achieve this, one is required to play the role of the person with whom s/he wants to establish empathy and look at events through his/her eyes by taking his/her place. When a person establishes empathy by playing the role of another, s/he has to stay in that individual's role for a short period of time and then get out of this role and take his/her place.

b. In order to have established empathy, we need to understand the thoughts and feelings of another person correctly. Making sense of only the thoughts or only the emotions of another person is not enough. In this sense, the concept of empathy has two components. These are the emotional and the cognitive components of empathy. Feeling what another individual feels exactly is an emotional activity; playing the role of another individual and making sense of what that individual feels is a cognitive activity.

c. It is the act of delivering the empathic understanding occurring in the individual establishing empathy to another person. Even if the thoughts and the emotions of another person are understood completely, the stage of establishing empathy is not completed if that person is told that $\mathrm{s} / \mathrm{he}$ has been understood.

Empathy is regarded as the foundation of emotion and accepted as the center of social behaviors. High level of empathy has been associated positively with the ability to perceive, express, understand, use and manage emotions (Eisenberg et al., 2003; cited by Salovey \& Detweiler, 2008). Empathy is the ability to acquire the power of distinguishing experiences made in place of another person, in other words, effective states of other people and both an effective and a mental viewpoint repecting them (Garaigordobil, 2009). Empathy is a person's putting $\mathrm{him} /$ herself into another person's place during communication and trying to understand that person's emotions and thoughts correctly by looking at events through his/her eyes. Empathic understanding has the characteristic of making people get close and faciliate communication in almost every part of daily life. When people are empathized with, they feel being understood and attached importance (Yüksel, 2004; cited by Arslan, 2016).

The importance of empathy level in human life arises from its causing changes in people's behaviors. It is observed that people with different empathy levels exhibit behavior patterns in different forms (Topcu et al., 2010). Empathy is the ability to enter another person's world which can be defined as the ability to see connections underlying behaviors, emotions and thoughts arising during interaction with a person and nearly understand what that person has lived (Ivey, Ivey \& Morgan, 1997; cited by Bal \& Bilge, 2016). As powerful communication ability, empathy is stated as understanding what speaker thinks and feels, needs at that time and delivering back to that person without judging him/her. Sensitivity, tolerance, helpfulness, democratic personality which empathy might make a student/an individual acquire, the wideness of the bundle of personal characteristics such as the ability to see social events and situations from a broad perspective and the deepness of the effects of these acquisitions on the quality of interpersonal relations in the society bring it forward as a skill which requires making new generations acquire (Kabapınar, 2005).

It is observed that empathy is generally confused with other concepts. For example, it was expressed that a person's just putting him/herself into another person's place or taking that person's perspective was evaluated as empathy, but these concepts had different dimensions (Davis, 2001). An empathic person cannot remain insensitive to people around him/her, but behave sensitively (Arslan, 2016). In people who can establish empathy, the behavior of helping comes into existence by itself. A person's putting him/herself into another person's place and looking at events from that person's perspective bears the behavior of helping (Schultz, 2001). 


\subsection{Relationship Between Social Studies and the Skill of Empathy}

One of the most important courses, in which students are made to acquire the knowledge, skills and values required to become effective citizens, is the Social Studies course. The Social Studies course aims to raise students as good and happy citizens playing their roles in the society, establishing good relations with others, being able to work in cooperation and adapt to their environment (Öztürk et al., 2002). In the realization of these aims, communication has an important place. And empathy has a very important place in the establishment of effective communication. The research results related to possible acquisitions of the individual and the society in case of developing the sense and skill of empathy indicate that empathy is a subject which is worth dwelling upon in courses related to Social Studies (Öztürk \& Dilek, 2005). Skills are capabilities aimed to have students acquire, develop and transfer to life within the learning process. In the Ministry of National Education, Social Studies Course Teaching Program, the Basic skills were listed as follows (MEB, 2018): Research, environmental literacy, perceiving change and continuity, digital literacy, critical thinking, empathy, financial literacy, entrepreneurism, observation, map literacy, law literacy, communication, cooperation, noticing stereotypes and prejudices, use of proof, making a decision, location analysis, media literacy, space perception, self-control, political literacy, problem solving, social participation, drawing and interpreting tables, graphs and diagrams, using Turkish accurately and eloquently, innovative thinking and perceiving time and chronology.

In the social studies teaching program (Primary and Secondary 4th, 5th, 6th and 7th Grades), it is stated that the rapid change experienced in science and technology, the changing needs of the individual and the society, the novelties and developments in learning and teaching-learning theories and approaches have directly affected the roles expected from individuals as well. This change defines an individual having such qualities as generating the knowledge, using it functionally, being capable of solving problems, thinking critically, being entrepreneurial and decisive, having communication skills, being capable of empathizing with others, making contributions to the society and culture, etc. The programs to serve the raising of individuals having these qualities have been prepared not in a structure transferring knowledge only but rather in a simple and understandable structure that pays attention to individual differences and aiming to have them acquire values and skills. In this context, it is regarded as necessary to make students acquire such values as respect and responsibility and the skills of using evidence, perceiving time and chronology and establishing empathy while teaching the learning domain of "Individual and Society"; similarly, it is also required to make them acquire such values as sensitivity and respect to cultural heritage and such skills as research and empathy while teaching the learning domain of "Global Connections" (MEB, 2018).

By including the concept of empathy in social studies lessons, students can be better introduced the geographical characteristics of the environment and the world in which they live and the interaction between people and natural environment can be established. It is stated that children with developed ability to establish empathy are better at approaching animals, become more successful in their lessons, develop social behaviors and achieve considerable developments in suggesting help and emotional support to people who are in a difficult situation (Öztürk \& Dilek, 2005).

Thanks to education, individuals who can think, question, produce, research and discuss are raised. In this process, establishing an effective communication is very important. And empathy has a very important place in the establishment of an effective communication. In almost every part of daily life, empathic understanding makes people get close to each other and facilitates communication (Öztürk, 1993). In educational environments, empathy bears a separate importance in terms of both being a tool for establishing a healthy communication between educators and students and preparing and implementing education programs and a characteristic which requires having people planning to work in education sector in the future acquire (Köksal \& Koçer, 2005). Empathy helps to establish strong and healthy relationships, increase communication and decrease conflict. Empathy helps an individual get on better with people who are different or come from other cultures. A person aiming to understand another person by looking at his/her world from his/her point of view can establish a healthy communication. Empathic people are polite to others and feel that they are doing good things for them, which develop individual happiness and positive emotions (Wei et al., 2011). For this reason, teachers with developed empathy skills are needed. Ergin (2012) states that "a teacher should possess such characteristics as being patient and considerate, having empathic ability and possessing positive thoughts towards students and being good-humored. The communication skills which a teacher possesses are of importance in terms of the quality of teaching. No matter how much information a teacher possesses, if $\mathrm{s} / \mathrm{he}$ cannot establish an effective communication with his/her student, in other words, if s/he cannot understand his/her needs completely, that teacher's information becomes meaningless as well as the education which the teacher gives to his/her student will be rather limited and inefficient (Demir, 2012). 
After the social studies teaching, the concept of empathy and the relationship between the social studies teaching and the skill of empathy had been looked into, the postgraduate theses made in this field in Turkey were examined in terms of various variables.

\subsection{The Purpose of the Study}

The skill of empathy included among the basic skills in the Social Studies course teaching program is one of the most basic skills which requires having students acquire. For this reason, it is rather important that firstly teachers should possess the skill of empathy. Many postgraduate theses are available on the concept of empathy. In this study, it was aimed to reveal how the postgraduate students taking education in the Turkish universities studied the skill of empathy included in the social studies course teaching program in terms of various variables. This study examined the master's and the doctoral theses carried out at the Turkish universities between 2000 and 2019 and taking in hand the relationship between the Social Studies Education and the skill of empathy based on various variables. The theses were reached at the official website of the Higher Education Council National Thesis Center. The postgraduate theses were examined based on the publication year of the thesis, the gender of the researcher, the university where it was published, the type of the sample group, the method of the investigation and the subject of the study. This study is important in terms of creating a resource for both the field of social studies education and further academic studies to be made on the skill of empathy. Moreover, it is considered that the present study will provide information about the characteristics of the existing theses for researchers to study the skill of empathy.

\section{Method}

\subsection{The Research Model}

This study examined the postgraduate theses written on the skill of empathy included in the field of Social Studies education in Turkey. In line with the purpose of the study, the document analysis method, one of the qualitative research methods, was used. The document analysis method is used to analyze written materials about a phenomenon desired to be studied without feeling the need for doing observations or holding interviews (Y1ldirım \& Şimşek, 2016).

The sample of the study is composed of all the postgraduate theses written on the skill of empathy in the field of social studies education, published between the years of 2000 and 2019 and recorded at the official website of HEC National Thesis Center. In the determination of the sample of the study, the criterion sampling method, one of the purposeful sampling methods, was used. The criterion sampling is the deep analysis of all situations meeting predetermined criteria (Yıldırım \& Şimşek, 2016). The purposeful sampling is chosen in knowledge-rich cases with the aim of conducting in-depth research (Büyüköztürk, 2012). The purposeful sampling method is the form of sample occurring as a result of putting a certain criterion on the sample under discussion (Büyüköztürk et al., 2009).

\subsection{Sample and Data Collection}

The data of the study was collected by the researcher between the dates of $25^{\text {th }}$ September and $25^{\text {th }}$ November, 2019. In the study, the master's and the doctoral theses published under the heading of empathy in the field of social studies education were scanned in the database of the "National Thesis Center" of the Higher Education Council by using the keywords of "Social Studies" and "empathy". As a result of the scanning of the database, a total of 17 postgraduate theses, 13 master's and 4 doctoral, were selected from among the ones which were written under the heading of the skill of empathy included in the field of social studies education and published between 2000 and 2019.

\section{Result}

a. In the following table, the distribution of the postgraduate theses written on the skill of empathy in the social studies education was given according to years. 
Table 1. Distribution of the postgraduate theses written on empathy in the social studies education according to years

\begin{tabular}{ccccccc}
\hline Year & \multicolumn{2}{c}{ Master's } & \multicolumn{2}{c}{ Doctoral } & \multicolumn{2}{c}{ Total } \\
\hline & $N$ & $\%$ & $n$ & $\%$ & $n$ & $\%$ \\
\cline { 2 - 7 } 2019 & 4 & $31 \%$ & & & 4 & $24 \%$ \\
2018 & 1 & $8 \%$ & & & 1 & $6 \%$ \\
2017 & 1 & $8 \%$ & - & & 1 & $6 \%$ \\
2015 & 1 & $8 \%$ & - & & 1 & $6 \%$ \\
2013 & & $0 \%$ & 3 & $75 \%$ & 3 & $18 \%$ \\
2012 & 1 & $8 \%$ & - & & 0 & $0 \%$ \\
2011 & 3 & $23 \%$ & & & 3 & $18 \%$ \\
2010 & 1 & $8 \%$ & & & 1 & $6 \%$ \\
2007 & 1 & $8 \%$ & 1 & $25 \%$ & 2 & $12 \%$ \\
Total & 13 & $100 \%$ & 4 & $100 \%$ & 17 & $100 \%$ \\
\hline
\end{tabular}

The number of the theses was the highest in 2019. The number of these theses is 4 they were master's theses. The first doctoral and master's theses were completed in 2007. No theses completed in the years of 2008, 2009, 2014 and 2016 were reached. When the number of the theses wrriten in the field of social studies education and recorded at the Thesis Center is looked into, it is observed to be insufficient. The increase observed in number of theses produced in Turkey in recent years can be linked to the increase in the number of programs giving postgraduate education.

b. In the following table was given the distribution of the postgraduate theses written on the skill of empathy included in the field of social studies education according to the gender of researcher.

Table 2. Distribution of the postgraduate theses written on the skill of empathy in the field of social studies education according to the gender of researcher

\begin{tabular}{ccccccc}
\hline Gender & \multicolumn{2}{c}{ Master's } & \multicolumn{2}{c}{ Doctoral } & \multicolumn{2}{c}{ Total } \\
\hline & $\mathrm{n}$ & $\%$ & $\mathrm{n}$ & $\%$ & $\mathrm{n}$ & $\%$ \\
Female & 6 & 46 & 3 & 75 & 9 & 53 \\
Male & 7 & 54 & 1 & 25 & 8 & 47 \\
Total & 13 & 100 & 4 & 100 & 17 & 100 \\
\hline
\end{tabular}

When the theses included in the study were examined, it was seen that 9 of the researchers were female and 8 of them were male. When the master's theses were examined, the number of the male researchers was higher than that of the female researchers. 6 of the master's theses were written by female and 7 of them were written by male students. When the doctoral theses were examined, it was found that 3 theses were written by female and 1 thesis was written by male students.

c. In the following table was given the distribution of the postgrduate theses written on the skill of empathy in the field of social studies education according to the university where they were published. 
Table 3. Distribution of the postgraduate theses written on the skill of empathy in the field of social studies education according to the university where they were published

\begin{tabular}{ccccccc}
\hline University & \multicolumn{2}{c}{ Master's } & \multicolumn{2}{c}{ Doctoral } & \multicolumn{2}{c}{ Total } \\
\hline & $n$ & $\%$ & $n$ & $\%$ & $n$ & $\%$ \\
\cline { 2 - 7 } Marmara University & 4 & $31 \%$ & 1 & $25 \%$ & 5 & $29 \%$ \\
Atatürk University & 0 & $0 \%$ & 2 & $50 \%$ & 2 & $12 \%$ \\
Gazi University & 0 & $0 \%$ & 1 & $25 \%$ & 1 & $6 \%$ \\
Sakarya University & 3 & $23 \%$ & - & $0 \%$ & 3 & $18 \%$ \\
Recep Tayyip University & 1 & $8 \%$ & - & $0 \%$ & 1 & $6 \%$ \\
Aksaray University & 1 & $8 \%$ & - & $0 \%$ & 1 & $6 \%$ \\
Bartın University & 1 & $8 \%$ & - & $\%$ & 1 & $6 \%$ \\
Afyon Kocatepe University & 1 & $8 \%$ & - & $0 \%$ & 1 & $6 \%$ \\
Celal Bayar University & 1 & $8 \%$ & - & $0 \%$ & 1 & $6 \%$ \\
Bolu Abant İzzet Baysal University & 1 & $8 \%$ & - & $0 \%$ & 1 & $6 \%$ \\
Total & 13 & $100 \%$ & 4 & $100 \%$ & 17 & $100 \%$ \\
\hline
\end{tabular}

When the distribution of the master's and the doctoral theses written on the skill of empathy in the field of social studies education was examined, it was observed that they were written at a total of 10 universities. In the lead of them was the Marmara University. It is observed that all of the postgraduate theses included in the study were written at state universities. 4 of the master's theses and 1 of the doctoral theses were written at the Marmara University. It was also observed that 2 doctoral theses were written at Ataturk University 1 doctoral thesis was written at Gazi University. That the number of the postgraduate theses was higher at these universities can be explained by the foundation years of these universities and their having more academic staff.

d. When the postgraduate theses written on the skill of empathy in the field of social studies education were examined in terms of sample groups, it was found that the studies were made with social studies teachers, social studies preservice teachers and students. When the doctoral theses were looked into, it was seen that 1 of them was made with teachers, 3 of them were made with students. In the master's theses, 9 of the studies were made with students, 2 of them were made with preservice teachers and 2 of them were made with teachers. It was observed that a total of 12 studies were made with students, 3 of them were made with teachers and 2 of them were made with preservice teachers.

If we are to sum up briefly the doctoral theses written on the skill of empathy in the social studies education between 2000 and 2019 in terms of their subjects and methods of investigation, we can mention some previous studies:

For example, Elikesik (2013) aimed to determine the importance of the skill of empathy in the Social Studies teaching by looking into the Social Studies teachers' empathy skills according to some variables. In the study, the quantitative and the qualitative research designs were used together.

Moreover, we can also mention another study made by Yontar (2013) with the aim of examining the relationship between the value of responsibility and the skill of empathy, which were generally desired to have students acquire in the Social Studies Program. In this direction, the relationship between the fifth grade students' responsibility and empathy levels was examined in terms of gender, the Social Studies course achievement score and the school's socioeconomic level. In the study, the mixed method, in which the qualitative and the quantitative research methods are employed, was used.

Yet another study made by Yılmaz (2013) examined if the drama technique used in the Social Studies lessons had an effect on the social skill, empathy skill and academic achievement levels of the elementary 7th grade students. In the study, the Solomon Four-Group Research Model was used.

In another study made by Keskin (2007), the students' cognitive, affective, moral and social skills based on the activities, in which the skill of empathy is predominant, in the social studies lessons. Besides this, by revealing the empathic process, the students' developments were evaluated in this process. Moreover, the study was carried out by using action research, one of the qualitative research designs.

If we are to sum up briefly the master's theses written on the skill of empathy in the social studies education between the years of 2000 and 2019 in terms of their subjects and methods, we can mention some previous studies:

For example, Kaygısız (2019) prepared and practiced some activities with the aim of having the students acquire the historical empathy skill in the secondary school 7 th grade social studies course and then examined the 
effectiveness of these activities together with the students' opinions. The investigation into how much the students exhibited the characteristics of historical empathy and what they thought about the social studies lessons taught based on historical empathy according to student products/activities were the two basic problems of the study. In this study carried out based on action research, the evaluation was made based on descriptive analysis.

In another study, Çorapçı (2019) examined "the effect of the historical empathy activities in the 7th grade social studies course on academic success, permanence and attitude toward the course". The study group was composed of a total of 42 seventh grade students, 21 in the experimental group and 21 in the control group. The sets of quantitative data obtained from the academic achievement test and the social studies attitude scale were analyzed. The students' opinions about the historical empathy activities were evaluated by using the content analysis method.

Yet in another study, Güneş (2019) examined the acquisition of the historical empathy skill through the creative drama method, which is important in terms of learning historical subjects in the social studies course. For this purpose, within the scope of the social studies course, the subject entitled "Scholars Raised in Turkish Islamic States "was studied with the 7th grade students in an activity-based manner by using the creative drama method and the students' levels of acquiring the historical empathy skill were examined. The study group was composed of the 7 th grade students. In the study made via using the action research model, more than one data collection tools were used.

In another study, Demir (2019) examined the effect of the activities prepared based on historical empathy on the students' historical empathy skills and academic success levels in the social studies course. This study was carried out with 42 seventh grade students during the 2018-2019 educational year. In the study, the semi-experimental design with pretest-post-test with control group was used. In the study, as a data collection instrument, the "Historical Empathy Scale "developed by Çalışkan and Demir (2019) was used.

Again, in another study, Konuk (2018) aimed to examine the effect of the activities performed based on the skill of empathy in the social studies course on the students' environmental awareness and academic success levels. The study group was composed of a total of 51 students, 22 female and 29 male, taking education in two different classes in a public secondary school in Aksaray. In the stage of collecting the data, the "Environmental Awareness Scale" developed by Uzun, Sağlam, and Varnaci-Uzun (2008) and the "Achievement Test" formed by the researcher by considering the unit acquisitions and expert opinions were used.

In another study, Çatlak (2017) generally aimed to examine the effect of the storyline method on having the social studies preservice teachers acquire the skill of empathy and the value of respect for differences in the context of multiculturalism. This study was made experimentally with 20 students selected from among the 3rd year classroom teaching preservice teachers and taking values education as an elective course in the fall semester of the 2015-2016 academic year at Abant İzzet Baysal University Social Studies Education Department. 10 of the students were assigned to the experimental group and 10 of them to the control group.

In another study, Tartuk (2015) aimed to examine the social studies preservice teachers' critical thinking and empathy establishing tendencies. In the study, it was investigated if the preservice teachers' critical thinking and empathy establishing tendencies differed according to their univeristies and class levels, genders, ages, parants' educational statuses and perceived socio-economic levels. In the study, sicnce the social studies preservice teachers' critical thinking and empathy establishing tendencies tried to be determined, it was a descriptive study baed on screening model.

Again, in another study, Aysal (2012) examined the effect of the role-play method based on historical empathy on academic success in the elementary 7 th grade social studies course. The study was carried out with two separate classes in the 2010-2011 educational year at the resarch school. In the study, the action research with the pretest-posttest control group model was used. The pretest and posttest were used as a measurement tool. Moreover, an interview form was developed to take the students' opinions.

In another study, Duman (2011) aimed to examine the 6th and the 7th grade social studies teaching materials in terms of the skill of empathy in the dimensions of aim, scope and effectiveness. The working group of the study arranged in accordance with case study, one of the qualitative reserch methods, was composed of two sections. In the study, interviews were held with the teachers by using a semi-structured interview form composed of 7 questions and voice records were transcribed.

In another study, Kaya (2011) aimed to examine the 4th and the 5th grade Social Studies teaching materials in terms of the skill of empathy in the dimensions of aim, scope and effectiveness. The working group of the study arranged in accordance with case study, one of the qualitative research methods, was composed of two sections. In the study, a semi-structured interview form composed of 7 questions was used. The obtained data was analyzed via 
using the content analysis method.

Yet, in another study, Akyol (2011) aimed to determine the effect of associating the "Journey in the Turkish History" unit with children's literature products when studying this unit in the elementary 7th grade Social Studies course on the students' empathic tendencies. The study was carried out at a secondary school in the 2010-2011 educational year. The study was carried out with a total of 34 students, one experimental and one control group. Both prior and subsequent to the practice, both groups were administered the empathic tendency scale composed of 20 items.

The main aim of Ural's (2010) study was to reveal the role of the elementary 6th and 7th grades social studies courses on the acquisition of democratic attitude and empathic tendency via analyzing the students' opinions. The population of the study was composed of the 6 th and the 7 th grade students taking education at 4 primary schools in Sakarya in the 2008-2009 educational year. In the study, the Democratic Attitude Scale prepared by the researcher and the Empathic Tendency Scale prepared by Üstün Dökmen (1988) were used.

In Uğur's (2007) study, it was aimed to reveal the effect of the use of the case study technique in the constructionist social studies teaching on the students' empathic thinking skills. The study was carried out with 27 elementary 6 th grade students. In this study, since they were suitable for the subject and the purpose, the qualitative research methods and techniques were used. In the data collection process of the study, all the lessons were recorded with a video camera.

When the postgraduate theses taken within the scope of the study were examined, it was observed that the qualitative and the quantitative methods were used together in 2 of both the doctotal and the master's theses. 5 of the other master's and doctoral theses were carried out by using the qualitative methods and 8 of them were carried out by using the quantitative methods.

\section{Discussions}

One of the skills aimed to have students acquire in the social studies course teaching program is the skill of empathy. For this reason, it is important that teachers, who are supposed to implement the Social Studies program, should possess the capability of having students acquire the skills of the Social Studies course. For, students need skills to turn the information they acquire and the values they possess into behaviors. One of these skills is the skill of empathy. With this study, the theses written at postgraduate level on the skill of empathy in the field of social studies education were investigated.

In the section where the postgraduate theses written on empathy in the field of social studies education between the years of 2000 and 2019 were examined, 17 postgraduate theses were examined and the following results were reached: 13 of the examined postgraduate theses were written at master's level and 4 of them were written at doctoral level. The majority of the theses determined in the study made by Karadağ (2014) were master's theses. The first master's and doctoral theses written on empathy in the social studies were published in 2007. The number of master's theses written in this field is higher than that of the doctoral theses. Besides this, the years in which the number of postgraduate theses was the highest were 2011, 2013 and 2019. The majority of the published theses were published within these years. There is only one thesis written in 2017 on empathy. In the years of 2008, 2009, 2014 and 2016, no postgraduate theses were published both at master's level and at doctoral level on empathy in the field of social studies education.

When the postgraduate theses were examined, it was observed that 9 theses were written by female students and 8 theses were written by male students. This makes us consider that female researchers show more interest in the subject. When the master's theses were examined, it was seen that the number of the male researchers was higher than that of the female researchers. 6 of the master's theses were written by female students and 7 of them were written by male students. When the doctoral theses were looked into, it was seen that 3 theses were written by female students and 1 thesis was written by male students. In the studies made by Özenç and Özenç (2013) and Haçat and Demir (2019), too, the number of the female researchers was higher than that of the male researchers.

When the distribution of the doctoral and the master's theses written on the skill of empathy in the field of social studies education was examined, it was seen that they were written at a total of 10 universities. In the lead of them was Marmara University. 4 of the master's theses and 1 of the doctoral theses were written at Marmara University. At Atatürk University, 2 doctoral theses were written and, at Gazi university, 1 doctoral thesis was written. That the number of the postgraduate theses was higher at these universities can be explained by the foundation years of these universities and their having more academic staff.

In a study examining the postgraduate theses written in the field of geography between the dates of 2006 and 2017 , Çiftçi (2017) reached the result that a great majority of the theses were written at Gazi, Marmara and Atatürk 
universities. This result shows paralelism with the data obtained from the present study.

When the postgraduate theses written on empathy in the field of social studies education were examined in terms of sample groups, it was seen that the studies were made with teachers, preservice teachers and students. It is seen that a total of 12 studies were made with students; 3 of them were made with teachers; 2 of them were made with preservice teachers. In their study, Haçat and Demir (2019) determined that most of the studies were made with secondary school students in the master's theses. This shows paralelism with the sample group results of the theses examined in the study.

In the study, the postgraduate theses written on the skill of empathy in the field of Social Studies Education were examined in terms of various variables. Starting from the findings and the results of the study, the following suggestions can be made: The postgraduate theses written in relation to various skills included within the field of Social Studies Education can be examined. Studies examining the effect of social studies lessons supported with activities based on the skill of empathy on students' success levels can be carried out. In relation to this matter, they can be encouraged to participate in such activities as seminar, symposium, etc. The number of studies taking in hand postgraduate theses using different data collection tools can be increased. Studies using various methods to measure the skills of empathy of teachers, preservice teachers in different branches can be carried out.

\section{References}

Akdağ, H. (2009). An evaluation of primary school 6th and 7th grade social studies curriculum according to students' views (Konya city, case Study). Selçuk University Social Science Institute Journal, 21, 1-14.

Akyol, Y. (2011). 7th classes of primary school social studies journey in Turkish history unit associate with children literature on effect empathy with the skills of students (Unpublished master's thesis). Celal Bayar University Social Science Institute, Manisa.

Arslan, Y. (2016). Who shows better empathy?-A micro sociological research over the empathy. Batman Üniversity Journal of Life Science, 6(2/1), 51-64.

Aysal, A. (2012). The effects of role playing technic based on historical empathy on academic success in social sciences lesson in 7th classes of primary school (Unpublished master's thesis). Afyon Kocatepe University Social Science Institute, Afyon.

Bal, P. N., \& Bilge, Y. (2016). The effect of empathy skill psycho-education program on gifted adolescents. HAYEF Journal of Education, 13(1), 23-36.

Büyüköztürk, Ş. (2012). Manual of data analysis for social sciences. Ankara: Pegem Akademi.

Büyüköztürk, Ş., Kılıç-Çakmak, E., Akgün, Ö. E., Karadeniz, Ş., \& Demirel, F. (2009). Scientific Research Methods (4th ed.). Ankara: Pegem Akademi.

Çatlak, İ. H. (2017). Effect of storyline method on enriching candidate teachers of social studies with empathy skills and value of respecting to differences (Unpublished master's thesis). Abant İzzet Baysal University Educational Science Institute, Bolu.

Çiftçi, T. (2017). Trends of geography education postgraduate thesis (2006-2017) made in Turkey. Journal of History Culture and Art Research, 6(4), 864-887.

Çorapç1, S. (2019). The effect of historical empathy activities in social studies course on academic achievement, permanence and attitudes of the students towards the course (Unpublished master's thesis). Recep Tayyip Erdoğan University Social Science Institute, Rize.

Davis O. L. (2001). In pursuit of historical empathy. In O. L. Davis, E. A. Yeager, \& S. J. Foster (Eds.), Historical empathy and perspective taking in the social studies. Rowman \& Littlefield Publishers: New York.

Demir, B. (2019). The effect of activities based historical empathy in social studies lesson on students' historical empathy skills and success (Unpublished master's thesis). Sakarya University Educational Science Institute, Sakarya.

Demir, M. K. (2012). Examination of classroom teacher candidates' empathy skills. Journal of Buca Education, $33,107-121$.

Doğanay, A. (2004). Social studies teaching. Ankara, Pegem Akademi.

Dökmen, Ü. (2013). Communication conflicts and empathy. İstanbul: Sistem publications.

Duman, M. (2011). Developing empathy skills using teaching materials in social studies lesson: Aim, involving 
empathy skills, usefulness (Unpublished master's thesis). Marmara University Educational Science Institute, İstanbul.

Elikesik, M. (2013). Empathy in social sciences teaching and the study of social sciences teachers empathic skills in terms of some variance (Unpublished doctoral thesis). Atatürk University Educational Science Institute, Erzurum.

Ergin, A. (2012). Effective communication in education. Ankara: Anı Publishing.

Ersoy, F., \& Kaya, E. (2008). The perceptions of students towards the social studies curriculum (2004) according to the opinions of classroom teachers. Anadolu University Journal of Social Sciences, 8(1), 285-300.

Garaigordobil, M. (2009). A comparative analysis of empathy in childhood and adolescence: Gender differences and associated socio-emotional variables. International Journal of Psychology and Psychological Therapy, 9(2), 217-235.

Güneş, S. (2019). An activity based action research aiming historical empathy thorough creative drama in social studies (Unpublished master's thesis). Bartın University Social Science Institute, Bartın.

Haçat, S, O., Demir, F.B. (2019). Analysis of Postgraduate Theses on Literacy in the Field of Education. The Journal of Anatolian Cultural Research (JANCR), 3(2), 116-145.

Kabapınar, Y. (2005). Empathy as a teaching method that can be used in life studies and social studies teaching with application and evaluation criteria. Journal of Values Education, 3(9), 119-142.

Karadağ, R. (2014). Analysis of studies on reading interest, attitudes and habit based on postgraduate theses: Sample of YÖK and Pro Quest databases. Pamukkale Üniversity Education Faculty Journal, 35(1), 1-17. https://doi.org/10.9779/PUJE619

Kaya, N. B. (2011). Analysis of the social studies (4th and 5th grades) teaching materials in terms of empathy skill in purpose, content and efficacy dimensions (Unpublished master's thesis). Marmara University Educational Science Institute, İstanbul.

Kaygisiz, N. (2019). Investigation of social studies courses held by historical empathy activities according to student products and views (Unpublished master's thesis). Sakarya University Educational Science Institute, Sakarya.

Keskin, S. C. (2007). Use of education techniques which is based on empathy skills in social studies (Unpublished doctoral thesis). Marmara University Educational Science Institute, İstanbul.

Köksal, A. A., \& Koçer, Ç. H. (2005). Determining empathic skill levels of preschool teacher candidates. Eurasian Journal of Educational Research (EJER), 21, 13-23.

Konuk, Y. (2018). The effect of activities that based on empathy skill to children's environmental consciovsness and their academic achievements (Unpublished master's thesis). Aksaray University Social Science Institute,

MEB. (2018). Ministry of National Education (4.5.6.7.) class social studies course teaching program. Ankara: MEB Publications.

Özenç, M., \& Özenç, E. G. (2013). Examınatıon of the methodology of master and doctoral theses prepared by elementary school teachers. Abant İzet Baysal University Education Faculty Journal, 13(1), 132-141.

Öztürk, C. (2006). Social Studies: An interdisciplinary view of social life. In C. Öztürk (Ed.), life science and social studies teaching, Constructivist approach (pp. 21-50). Ankara: Pegem A publishing.

Öztürk, C., \& Dilek D. (2005). Life studies and social studies programs, Life studies and social studies education. In C. Öztürk, \& D. Dilek (Eds.), Life science and social studies teaching. Ankara: Pegem A publishing.

Öztürk, C., Keskin, S. C., \& Otluoğlu, R. (2002). Literary products and written materials in social studies education. Ankara: Pegem publications.

Öztürk, H. (1993). Educational Sociology (8th ed.). Ankara: Hatiboğlu.

Salovey, P., \& Detweiler, B. T. (2008). Emotional intelligence. In M. Lewis. (Eds.), Handbook of emotions (pp. 533-547). New York: Guilford Press.

Schultz, P., W. (2001). Empathizing with nature: the effects of perspective taking on concern for environmental issues. (Statistical data included) Journal of social issues, Plenum publishing corporation, in association with the gale group and looksmart. 
Sönmez, V. (1999). Social studies teaching and teacher guide. Ankara, Anı publishing.

Tartuk, M. (2015). The investigation of social studies teachers' candidates disposition of critical thinking and empathy (Unpublished master's thesis). Marmara University Educational Science Institute, İstanbul.

Tezgel, R. (2006). Human Rights and value Education in the new primary school social studies curriculum. II. Applied Ethics Congress Proceedings Book (pp. 637-645).

Topçu, Ç., Baker, Ö. E., \& Aydın, Y. Ç. (2010). Turkish adaptation of basic empathy scale: Validity and reliability study. Turkish Psychological Counseling and Guidance Journal, 4(34), 174-182.

Uğur, A. (2007). The effect of case study technique as a teaching practice on pupils'empathic thinking skills in the constructivist social studies classroom: An action research (Unpublished master's thesis). Marmara University Educational Science Institute, İstanbul.

Ural, S. N. (2010). Democratik attitudes and empathy to primary school students level of influence of social science courses (Unpublished master's thesis). Sakarya University Social Science Institute, Sakarya.

Uzun, N., Sağlam, N., \& Uzun-Varnacı, F. (2008). The effect of the green class model based applied environmental education project on environmental consciousness and its retention. Ege Education Journal, 9(1), 59-74.

Wei, M., Liao, K. Y. H., Ku, T. Y., \& Shaffer, P. A. (2011). Attachment, self-compassion, empathy, and subjective well-being among college students and community adults. Journal of personality, 79(1), 191-221. https://doi.org/10.1111/j.1467-6494.2010.00677.x

Yiğit, E. Ö. (2007). The effect of storyline method on student achievement about the sources of our country unit in 6th grade social studies curriculum (Unpublished master's thesis). Abant İzzet Baysal University Social Science Institute, Bolu.

Yıldırım, A., \& Şimşek, H. (2016). Qualitative research methods in the social sciences. Ankara: Seçkin Publishing.

Yilmaz, S. (2013). Effect of education with drama method in social studies on the levels of social ability, emphathic ability and academic achievement of students (Unpublished doctoral thesis). Atatürk University Educational Science Institute, Erzurum.

Yontar, A. (2013). Investigating the relationship between responsibility value and empathy skill aimed to be gained in social studies program (Unpublished doctoral thesis). Gazi University Educational Science Institute, Ankara.

\section{Copyrights}

Copyright for this article is retained by the author(s), with first publication rights granted to the journal.

This is an open-access article distributed under the terms and conditions of the Creative Commons Attribution license (http://creativecommons.org/licenses/by/4.0/). 